\title{
Effects of Echinacea Purpurea on Cryptosporidiosis in Immunosuppressed Experimentally Infected Mice
}

\author{
AMANY F. ATIA, M.D.*; MARWA M. DAWOUD, M.D.** and SAMAR A. EL-REFAI, M.D.* \\ The Departments of Parasitology* and Pathology**, Faculty of Medicine, Menoufia University, Egypt
}

\begin{abstract}
Background: Cryptosporidium species are worldwide coccidian parasites. They are considered the second cause of diarrhea and death in children after rotavirus. Current treatment options for cryptosporidiosis are limited. There is an urgent need to develop new anti-cryptosporidial agents.
\end{abstract}

Aim of the Study: To assess the activity of Echinacea purpurea in treatment of experimental cryptosporidiosis in immunosuppressed mice.

Methods: Ninety mice were immunosuppressed using oral dexamethasone and divided into 5 groups. Echinacea was used as $100 \mathrm{mg} / \mathrm{kg} /$ day on day 15 post infection for five consecutive days. Stool samples from all survived mice were subjected to modified Ziehl-Neelsen staining. All mice were sacrificed for histopathological examination and immunohistochemical staining of their ilea sections for IL-17 and Cox-2.

Results: The least mortality rate $(0 \%)$, the least oocysts shedding (1.10 \pm 2.31$)$, the least endogenous developmental stages (3.50 \pm 2.24$)$, the most improved pathological changes and the highest cure rate $(90 \%)$ were observed in mice treated with Echinacea/nitazoxanide combination. Moreover, combination therapy significantly reduced IL-17 and Cox-2 expression in ileum sections compared to the positive control group. Echinacea monotherapy significantly reduced fecal oocyst shedding and ileal endogenous developmental stages with improved pathological changes compared to the positive control group. Echinacea increased the cure rate with no significant difference when compared to nitazoxanide. It significantly decreased IL-17 and Cox-2 in ileum sections compared to the positive control group.

Conclusion: Echinacea purpurea/nitazoxanide combination represents significant advances in treatment of experimental cryptosporidiosis infection in immunosuppressed mice.

Key Words: E. purpurea-Cryptosporidiosis - Immunomodulation - IL-17-Cox-2.

Correspondence to: Dr. Amany F. Atia, The Department of Parasitology, Faculty of Medicine, Menoufia University, Egypt

\section{Introduction}

CRYPTOSPORIDIUM is a worldwide protozoal infection that affects domestic and wild animals as well as humans causing cryptosporidiosis. They cause moderate to severe disease in humans. Cryptosporidium parvum (C. parvum) and C. hominis are the most frequently detected species infecting humans [1].

Cryptosporidium human infections are considered the second major cause of diarrhea and death in children after rotavirus [2]. Infection is usually acquired by feco-oral route through ingestion of food or water contaminated by the oocyst [3] Following oocyst ingestion, excystation occurs and four sporozoites are released. Sporozoites invade the apical regions of the enterocytes. Reproduction and gamete formation occur in intestinal epithelium with final formation of new oocysts [4]

In immunocompetent patients, cryptosporidiosis is usually asymptomatic. Symptomatic cases manifest by acute diarrhea or sometimes a persistent form is induced and lasts for few weeks. The diarrhea is usually watery and mucoid. Dehydration can result especially in children because of large volume of watery diarrhea. Prolonged infection can also results in malabsorption. In immunocompromised patients, infections are usually severe and life threatening [5]. Infection may affect pulmonary and hepatic tissues [6,7]. Moreover, cryptosporidiosis in early childhood can cause growth impairment, physical and mental retardation [8]

The immune system in cryptosporidiosis has an important role in controlling this infection [9] So, immunocompetent individuals have only a selflimited disease while immunocompromised patients usually suffer from persistent fatal disease [10] 
Both humoral and cellular immunity play important roles in controlling cryptosporidiosis, but the latter plays the major role, mainly in the intestinal mucosa.

The capacity to produce Th1, Th 2 and Th17 cytokines determines the effective immune response against $C$. parvum infection [11]. IL-17 is a proinflammatory cytokine secreted by Th17 cells. It was proved to play a role in host response to Cryptosporidium baileyi infection in chicken and was proved to enhance the inflammation during infection [12].

Sadek and El-Aswad, [13] reported that Cryptosporidium infection is associated with elevation of many cytokines which are the key stimulators of prostaglandin secretion. Also, cyclooxygenase2 (Cox-2) enzyme is essential for the synthesis of these prostaglandins. Prostaglandins contribute to Cryptosporidium induced diarrhea by altering chloride secretion and by causing sodium and glucose malabsorption. They concluded that the inflammatory effect of Cryptosporidium in intestine is mainly mediated by Cox-2 induction. Valdez et al., [14] reported that prostaglandin E2 (catalyzed by Cox-2) can also act on naive T cells and modulate IL-17 cytokine production which enhance Cryptosporidium induced inflammation.

Current treatment options for cryptosporidiosis are limited. Nitazoxanide (NTZ) is the only drug approved by the United States (US) Food and Drug Administration (FDA). Unfortunately, this drug exhibits only moderate clinical efficacy in children and immunocompetent individuals with no effect at all on immunocompromized patients $[15,16]$ Other anti-parasitic agents such as paromomycin and azithromycin are sometimes used, but they have only temporary effects and relapses have been recorded [17]. Furthermore, the duration of disease is only dependent upon the patient's immune status [18,19]

Thus, there is a great need to develop new anticryptosporidial agents. Trials were designed to test the potency of different agents for treating cryptosporidiosis. Gargala, [17] reported that the best approach for treatment of cryptosporidiosis is to improve the immune status.

Moreover, there has been a great interest in drugs that can selectively block Cox-2 enzyme as reduction of its levels will be an effective strategy for inhibiting inflammation as reported by Mulshine et al., [20] and Shishodia et al., [21] .
Echinacea is one of the oldest and most popular herbal species in the world. It is abundant throughout the world. It is useful in several inflammatory diseases and wound healing because of its immunomodulatory effects and regeneratide [22,23]. Also, preparations obtained from Echinacea purpurea (E. purpurea) leaves showed antibacterial, antifungal, antiviral, antiparasitic, immunomodulatory, anti-inflammatory and antioxidant effects, explaining its popular use against many infectious diseases for hundreds of years [24-27]. Echinacea was also used as a food supplementary, helping in treatment and prevention of many infections, especially in children, old aged and immunocompromised patients $[28,29]$. Extracts from Echinacea leaves decrease Cox-2 in a concentration dependent manner and interfere with IL-17 production [30,31].

Aim of the study:

The aim of this study was to assess the in vivo activity of $E$. purpurea in treatment of experimental cryptosporidiosis infection in immunosuppressed mice.

\section{Material and Methods}

\section{Experimental animals:}

Ninety male BALB/c albino mice (7-10 weeks old and $18 \pm 5 \mathrm{gm}$ ) were used. The animals were kept under controlled conditions of temperature $\left(25 \pm 2^{\circ} \mathrm{C}\right)$ and humidity $(70 \%)$. Mice were obtained from Schistosome Biological Supply Centre (SBSC), Theodor Bilharz Research Institute (TBRI), Giza, Egypt. They had free access to commercial diet and water. Bedding was changed every day. The mice were kept before Cryptosporidium infection for one week for adaptation, during this period, stool examination of the mice were done to be sure that they were parasites free. Daily observations were performed for all groups to record the mortality rate for each group. This study was approved by the Ethics Committee of TBRI and all procedures comply with the ethical standards of the national and institutional guides of the care and use of laboratory animals. The study was conducted from March 2017 to March 2018.

\section{Parasite preparation:}

Cryptosporidium oocysts (mostly C. parvum) were collected from feces of naturally infected diarrheic calves (1-2 months old) from a local dairy in Menoufia governorate. The samples were stained by modified Ziehl-Neelsen (MZN) method for confirmation of the presence of Cryptosporidium oocysts [32]. Positive fecal samples were washed by centrifugation (1500 $\mathrm{xg}$ for 10 minutes, 3 times) in Phosphate-Buffered Saline (PBS) and then they 
were sieved through a stainless steel sieve. The sieved materials were suspended in $2.5 \%$ potassium dichromate solution and stored at $4^{\circ} \mathrm{C}$ according to Arrowood and Sterling, [33] .

Samples were then purified using both ether extraction method to remove fat from feces followed by Discontinuous Sucrose Gradient (DSG) method according to Wee et al., [34]. Sheather's sucrose solution was prepared and diluted into two gradients; $1: 2$ and 1:4 in PBS. The first gradient solution $(10 \mathrm{ml})$ was placed into $50 \mathrm{ml}$ Falcon centrifuge tube and the second gradient solution $(10 \mathrm{ml})$ was slowly added. Fecal suspension (30 $\mathrm{ml}$ ) was then added. Falcon tubes were centrifuged at $1700 \mathrm{xg}$ for 30 minutes. The top layer was pipetted and discarded. Most Cryptosporidium oocysts were found at the interface which was aspirated and dispersed into PBS (80 ml). Oocysts were counted using a hemocytometer [35].

Mice groups:

Ninety mice were used in this study and classified into the following groups:

Group I (GI): Twenty immunosuppressed mice, infected with Cryptosporidium oocysts, not treated and served as positive control group.

Group II (GII): Twenty immunosuppressed mice infected with Cryptosporidium oocysts and treated with E. purpurea.

Group III (GIII): Twenty immunosuppressed mice infected with Cryptosporidium oocysts and treated with NTZ.

Group IV (GIV): Twenty immunosuppressed mice infected with Cryptosporidium oocysts and treated with E. purpurea and NTZ.

Group $V(G V)$ : Ten immunosuppressed mice, not infected, not treated and served as negative control group.

\section{Immunosuppression and mice infection:}

Mice were immunosuppressed using synthetic corticosteroid (dexamethasone) that was given orally at a dose of $0.25 \mathrm{mg} / \mathrm{Kg} /$ day for 14 successive days prior to infection according to Rehg et al., [36]. Then, each mouse in groups I, II, III and IV was infected orally with $10^{5}$ Cryptosporidium oocysts according to Suresh and Rehg, [35]. Dexamethasone was continued to be given at the same dose throughout the experiment.

\section{Drugs and dosage:}

Nitazoxanide was supplied as "Cryptonaz ${ }^{\circledR}$ " $60 \mathrm{ml}$ suspension of $100 \mathrm{mg} / 5 \mathrm{ml}$ by Copad Pharma (Egypt for Trade and Pharmaceutical industries,
Obour City, Cairo, Egypt). It was given orally to mice of GIII and GIV at a dose of $500 \mathrm{mg}$ twice daily starting on the 15 th day post infection (dpi) for five consecutive days. The dose was calculated according to the Paget and Barnes table $[37,38]$.

Echinacea purpureawas provided as an "Immunvita ${ }^{\circledR}$ " $25 \mathrm{ml}$ drops of $4.7 \mathrm{gm} / 25 \mathrm{ml}$ by EMA Pharm (Amriya for Pharmaceutical Industries, Cairo, Egypt). It was given orally to mice of GII and GIV at a dose of $100 \mathrm{mg} / \mathrm{kg} / \mathrm{day}$ starting on the 15 th dpi for five consecutive days according to Junior et al., [39].

\section{Samples collection and euthanizing of mice:}

From the 2 nd dpi, fresh fecal pellets were collected from each mouse separately and examined by MZN staining method to ensure establishment of infection.

On the 30th dpi, fresh fecal pellets were collected from each mouse separately and examined by MZN staining method to calculate Cryptosporidium oocysts shedding on the last day of the experiment.

Then, all the survived mice were euthanized by cervical dislocation [40]. Intestinal autopsies (ileum) were fixed in $10 \%$ neutral formalin and paraffin embedded. Serial sections were prepared for routine hematoxylin and eosin ( $\mathrm{H} \& \mathrm{E})$ staining and immunostaining of IL-17 and Cox-2.

\section{Stool samples MZN staining and examination:}

Fecal pellets were homogenized in a small volume of saline and sieved to remove the coarse fecal debris. Fecal smears were prepared and stained by MZN staining method [32]. Stained fecal smears were then examined microscopically and the number of Cryptosporidium oocysts was counted in 10 High Power Fields (HPFs). The mean number of oocysts/HPF for each mouse and then for each studied group was calculated.

\section{Histopathological examination:}

For histopathological examination, the terminal $2 \mathrm{~cm}$ of ileum of each mouse were fixed in $10 \%$ neutral buffered formalin and sectioned longitudinally. The sections were then processed as usual at the Pathology Department, Faculty of Medicine, Menoufia University before embedding in paraffin and mounted on glass slides. The cut sections were then immersed in xylene and graded alcohol followed by $\mathrm{H} \& \mathrm{E}$ staining. Endogenous developmental stages of the parasite were counted in the epithelium in $10 \mathrm{crypt} / \mathrm{villus}(\mathrm{C} / \mathrm{V})$ units; then the mean number per single $\mathrm{C} / \mathrm{V}$ unit for each animal and for each group was determined [41]. Patholog- 
ical changes were evaluated for each mouse including epithelial and lamina propria changes. Epithelial changes included $\mathrm{C} / \mathrm{V}$ ratio, blunting of villi, atrophy, hyperplasia, metaplasia, dysplasia, grade of dysplasia, inflammatory exocytosis, ulceration and degree of reactive atypia. Lamina propria changes included degree of inflammatory infiltrate, type of inflammatory infiltrate, congested blood vessels, edema and lymphoid aggregate. Degree of dysplasia in epithelium was estimated according to WHO classification of tumors of the digestive system [42].

\section{Immunohistochemical staining of IL-17 and} Cox-2:

Immunohistochemical staining was performed on 4 mick sections from the ileum of each mouse. Sections were dewaxed in xylene and rehydrated with ethanol followed by distilled water. Endogenous peroxidase activity was blocked by hydrogen peroxide. Then, sections were placed in citrate buffer ( $\mathrm{pH} \mathrm{6.0)}$ ), heated to $80^{\circ} \mathrm{C}$ for 10 minutes in a microwave oven and incubated with IL-17 mouse polyclonal antibody (Biorbyt, Catalogue number: A12934, Cambridge, United Kingdom) or Cox-2 mouse polyclonal antibody (Thermo scientific, catalogue number: PA1-84183, USA) which was diluted in $5 \%$ swine serum $(1: 100)$, for 60 minutes at room temperature. After washing with water, sections were incubated with the secondary antibody (biotinylated swine anti-rabbit immunoglobulin, 1:200 dilution) (Dako, Santa Clara, United States) for 30 minutes at room temperature and visualized using diaminobenzidine (DAB) as chromogen. Finally, sections were counterstained with Mayer's haematoxylin, dehydrated and mounted in xylene [43]

\section{Scoring of IL-17 expression:}

Scoring of sections was carried out by using a binocular Olympus light microscope at x400 magnification. Brownish cytoplasmic staining was considered positive. Values $<5 \%$ were considered negative. IL-17 expression was assessed in both epithelial covering and in the inflammatory cells in lamina propria. The staining intensity of the epithelium was estimated subjectively in $10 \mathrm{HPFs}$ and scored as follows: Score 0: Negative staining, score I: Mild staining, score II: Moderate staining and score III: Strong staining according to Du et al., [44] . Scoring for IL-17 expression in inflammatory cells in lamina propria was assigned by counting the positive cells in 5 HPFs and the mean count per slide and then per each group was calculated according to Fujino et al., [45].

\section{Scoring of Cox-2 expression:}

Staining of Cox-2 has been evaluated and scored in both epithelial covering and inflammatory cells in lamina propria. Brownish cytoplasmic staining was considered positive. Values $<5 \%$ were considered negative. The staining intensity in the epithelium was estimated subjectively in 10 HPFs and classified as negative, mild and moderate according to shamma et al., [46] . Regarding the extent of staining in inflammatory cells in lamina propria, it was considered negative if $<5 \%$ of cells were stained, focal if $6-50 \%$ of cells were stained and diffuse if $>50 \%$ of cells were stained according to Nofech-Mozes et al., [47].

\section{Statistical analysis:}

Data collected were tabulated and processed using SPSS (statistical pack-age for social science) Version 22.0 (SPSS Inc., Chicago, Illinois, USA) on IBM compatible computer. Normality of data was assessed by visual methods as well as ShapiroWilk test. Continuous variables were presented as mean \pm SD. The difference between two groups with non-parametric variables was analyzed by Mann Whitney test (U test). The Kruskal Wallis test (K test) was applied to study the difference between more than 2 groups having non-parametric variables. Fisher exact test was applied to compare qualitative variables when more than $25 \%$ of variables have observed values of less than 5 . Data were considered significant if $p$-value $<0.05$.

\section{Results}

\section{Mortality rate:}

At the end of study, mortality rate was $10 \%$ in the positive control groups (GI), $5 \%$ in groups treated by E. purpurae and NTZ monotherapy (GII and GIII) and $0 \%$ in GIV that received combined treatment.

\section{Oocyst shedding on the last day of the experiment:}

The least shedding of Cryptosporidium oocysts was observed in GIV, where mice were treated with $E$. purpurea/NTZ combination (mean $=1.10 \pm$ 2.31) with significant difference when compared to the positive control group (GI) and to those treated with E. purpurea monotherapy (GII) ( $p 3$ and $p 5<0.001)$. The difference was not significant when compared to those treated with NTZ alone (GIII) ( $p 6=0.89)$. Regarding usage of E. purpurea as a single therapy (GII), E. purpurea showed significant reduction of the mean Cryptosporidium oocyst in stool (mean $=6.94 \pm 3.77)$ with significant difference when compared to the positive control groups $(\mathrm{GI})(p 1<0.001)$. Although the mean count 
was still significantly higher than other treated groups (GIII and GIV) ( $p 4=0.02$ and $p 5<0.001)$ (Table 1) and Fig. (1).

\section{Histopathological examination:}

Several degrees of inflammatory changes varying from mild, moderated to severe were seen in the infected groups. Sections of ileum of positive control group (GI) showed mucosal hyperplasia and decreased $\mathrm{C} / \mathrm{V}$ ratio with blunting of villi in $94.4 \%$ of survived mice. All survived mice in this group showed low grade dysplasia, moderate reactive atypia and goblet cells depletion in the covering epithelium. In addition to dense inflammatory infiltrate in lamina propria. The endogenous developmental stages of Cryptosporidium in this group were easily seen either on the tip of the villi or within the epithelium (mean $=31.72 \pm 4.14)$ (Table 2 ) and Fig. (2A). In mice treated with E. purpurea alone (GII), sections showed preserved polarity of epithelium and decreased $\mathrm{C} / \mathrm{V}$ ratio in $84.2 \%$ of survived mice with mild to moderate chronic inflammatory infiltrate in lamina propria in $78.94 \%$ and $21.06 \%$ of survived mice, respectively. Cryptosporidium endogenous developmental stages were still seen (mean $=14.21 \pm 3.44$ ) within the epithelium but significantly decreased when compared to GI $(p 1<0.001)$ (Table 2) and Fig. (2B). Sections of mice treated with NTZ as a single therapy (GIII) showed blunted villi, decreased $\mathrm{C} / \mathrm{V}$ ratio, low grade dysplasia in $50 \%$ of mice and moderate reactive atypia of the epithelial covering in $27.7 \%$ of treated mice. Lamina propria showed variable degrees of inflammatory infiltrate. Endogenous developmental stages were still noted but in less numbers (mean $=7.21 \pm 2.72$ ) with significant difference when compared to GI and GII ( $p 2<0.001$ and $p 4=0.03$ ) (Table 2) and Fig. (2C). In contrast, sections taken from mice treated with combined therapy (GIV) showed only the house keeping inflammatory cells and hardly seen Cryptosporidium endogenous developmental stages (mean= $3.50 \pm 2.24)$ that was significantly lower than the other treated groups (GII and GIII) ( $p 5$ and $p 6<0.001)$. In addition, the epithelium of this group showed preserved polarity and was devoid of any cytologic atypia (Table 2) and Fig. (2D).

\section{Cure rate:}

According to the presence of Cryptosporidium oocysts in MZN stained stool smears and the presence of endogenous stages of Cryptosporidium in $\mathrm{H} \& \mathrm{E}$ stained ileal sections, the cure rate at the end of the experiment for different used treatments was calculated. It was the highest for the combi- nation therapy (GIV) $(90 \%)$ with a significant difference when compared to GII that received $E$. purpurea monotherapy ( $p 5=0.0022)$. This difference was not significant when compared to GIII that was treated with NTZ alone ( $p 6=0.127)$. NTZ treatment in GIII recorded $68.4 \%$ cure rate followed by those received E. purpurea in GII ( $42.1 \%)$ with no significant difference $(p 4=0.1)$ (Table 3$)$.

\section{Immunohistochemical staining of IL-17:}

Sections of positive control group (GI) exhibited strongly positive staining of IL-17 in $100 \%$ of the covering epithelium of survived mice. Moreover, positive cytoplasmic staining was detected in $374.0 \pm 47.7$ of the infiltrating chronic inflammatory cells (lymphocytes, macrophages and plasma cells) in lamina propria (Table 4) and Fig. (3A). Regarding IL-17 expression in the epithelial covering of GII and GIII, it was detected in (73.7\%) in both groups but in variable intensity. It varied from mild to moderate intensity in GII Fig. (3B); however in GIII, all positive sections were of strong intensity Fig. (3C). GII and GIII also showed significant differences in expression of IL-17 in lamina propria infiltrating cells when compared to GI ( $p 1$ and $p 2<0.001)$, with no significant difference between the two groups $(p 4=0.30)$ (Table 4$)$ and Fig. $(3 B, C)$.

IL-17 expression was noted in $75.0 \%$ of the epithelium of GIV with moderate intensity. Furthermore, sections of this group showed considerably decreased IL-17 expression in the inflammatory cells in lamina propria $($ mean $=32.25 \pm 16.41)$ with significant difference when compared to GI, GII and GIII ( $p 3, p 5$ and $p 6<0.001)$ (Table 4$)$ and Fig. (3D). The negative control group showed no IL-17 expression in the epithelial covering nor in lamina propria.

\section{Immunohistochemical staining of Cox-2:}

Regarding Cox-2 immunohistochemical stain, most sections of ilea of mice of the positive control group (GI) showed moderate expression of Cox2 in epithelial cells as well as diffuse expression in inflammatory cells in lamina propria (77.8\%) (Table 5) and Fig. (4A). While mice treated with E. purpurea monotherapy (GII) showed negative expression of Cox-2 in epithelium (100\%) and focal expression in inflammatory cells in the lamina propria (78.9\%) (Table 5) and Fig. (4B). In contrast diffuse expression was detected in inflammatory cells in GIII treated with NTZ alone (68.4\%) (Table 5) and Fig. (4C). Sections of GIV that received combined therapy, showed only mild expression of Cox-2 in the epithelium of most survived mice 
$(75.0 \%)$ and negative expression in the inflammatory cells in lamina propria (95\%) (Table 5) and Fig. (4D) with significant difference from GI, GII and GIII ( $p 3, p 5$ and $p 6<0.001)$ (Table 5). The negative control group $(\mathrm{GV})$ showed completely negative expression of Cox-2.

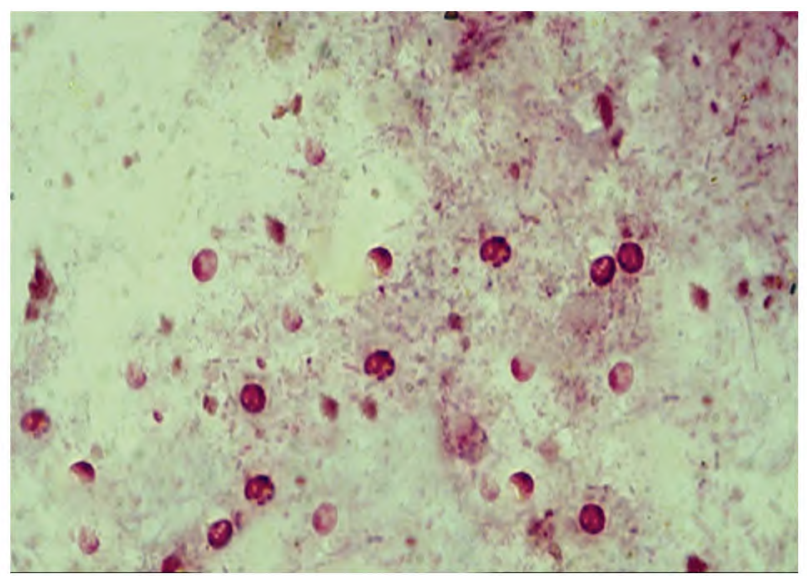

Fig. (1): Cryptosporidium oocysts in stool sample of an immunocompromised mouse (MZN, X1000).
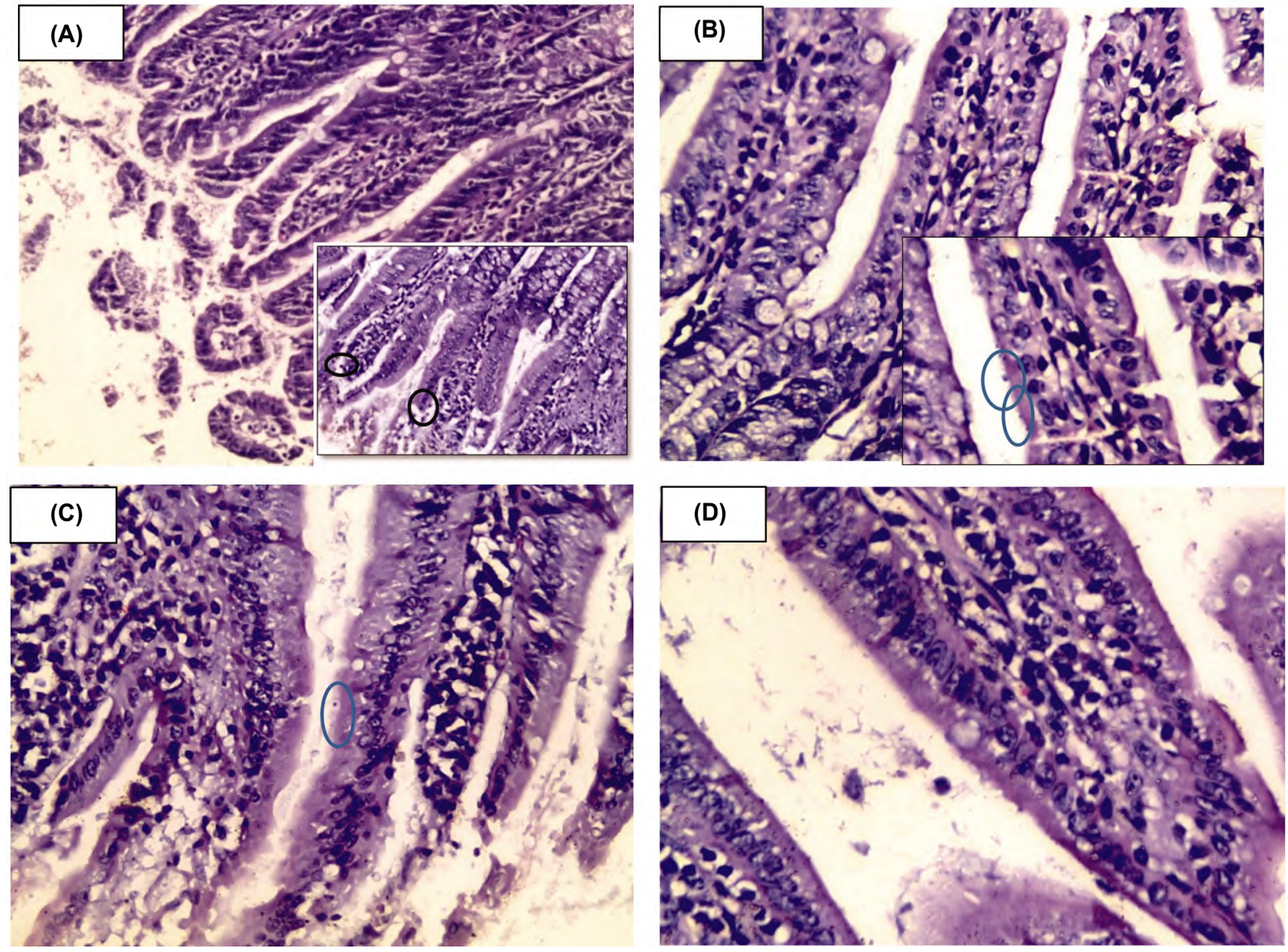

Fig. (2): (A): Ileum tissue of positive control group (GI) showing hyperplasia and blunting of villi with goblet cells depletion. The endogenous developmental stages of Cryptosporidium are highlighted with circles on or in the lining epithelium (H \& E, X200). (B): Ileum tissue of GII that received E.purpurea monotherapy showing moderate inflammatory infiltrate in cores of villi. The endogenous developmental stages of Cryptosporidium are highlighted with circles $(\mathrm{H}$ \& E, X400). (C): Ileum tissue of GIII that received NTZ monotherapy showing low grade dysplasia and severe inflammatory infiltrate. The endogenous developmental stage of Cryptosporidium is highlighted with a circle $(\mathrm{H} \&$ E, X400). (D): Ileum tissue of GIV that received combined therapy showing preserved polarity of epithelium (H \& $\mathrm{E}, \mathrm{X} 400)$. 

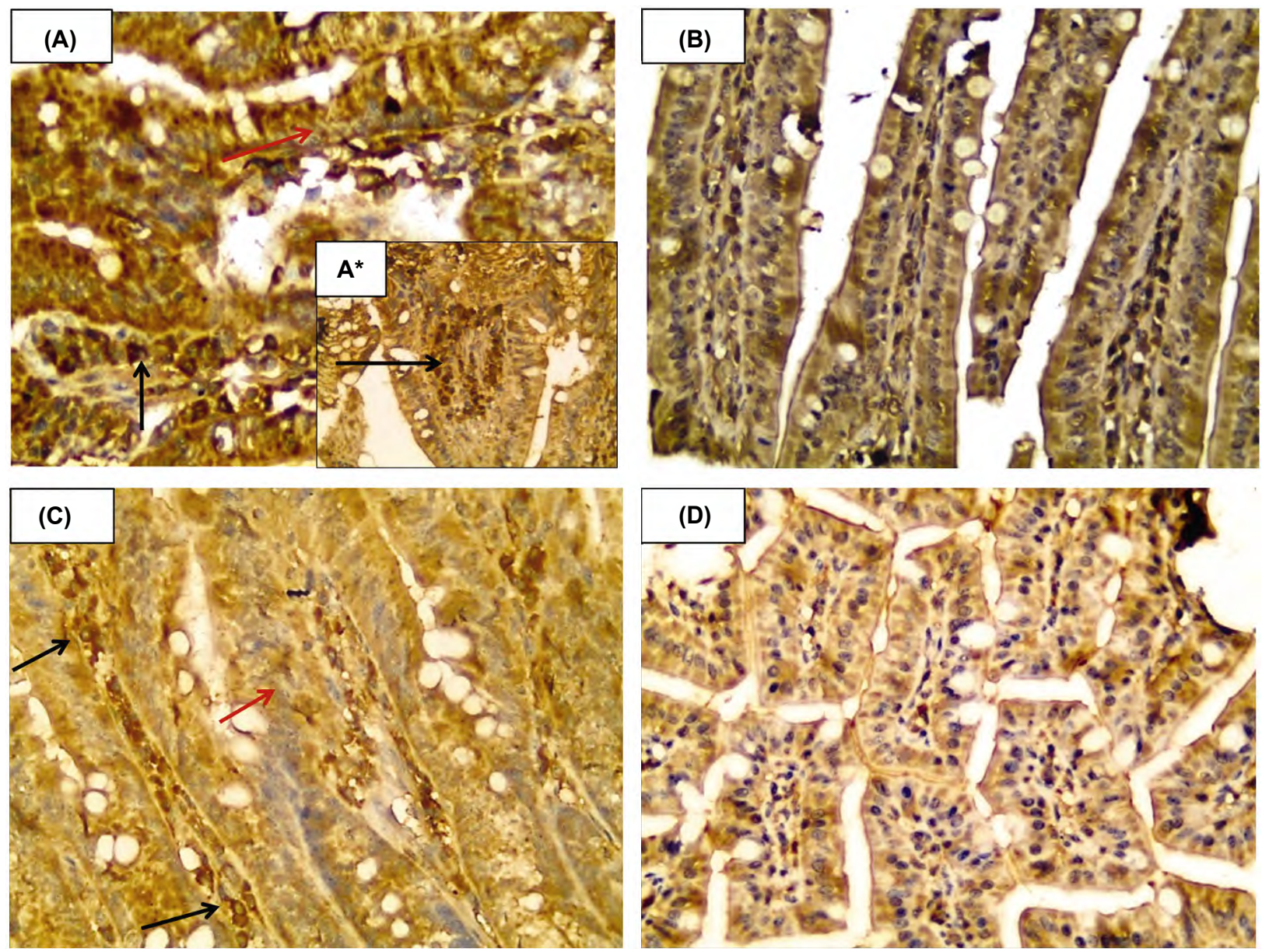

Fig. (3): (A): Ileum tissue of positive control group (GI) showing strong cytoplasmic expression of IL-17 in the inflammatory cells (black arrowed) occupying cores of the intestinal villi as well as epithelial covering that displays signs of low grade dysplasia (red arrowed) (IL-17 immunostain, X400). (A*) Another field of A showing dense infiltration of villi core by inflammatory cells expressing IL-17 (Black arrowed) (IL-17 immunostain, X400). (B): Ileum tissue of GII that received $E$. purpurea monotherapy showing mild expression of IL-17 in epithelial covering as well as in the inflammatory cells (IL-17 immunostain, X400). (C): Ileum tissue of GIII that received NTZ monotherapy showing strong expression in epithelial covering that displays signs of low grade dysplasia (red arrowed) as well as the moderate inflammatory infiltrate (black arrowed) in the core of the intestinal villi (IL-17 immunostain, X400). (D): Ileum tissue of GIV that received combined therapy showing significant reduction in staining of IL-17 in cores of the intestinal villi with moderate expression in epithelial covering (IL-17 immunostain, X400).

Table (1): Comparison between mean Cryptosporidium oocysts/HPF in stool samples of the different studied groups on the last day of the experiment.

\begin{tabular}{llll}
\hline \multirow{2}{*}{ Groups } & \multicolumn{3}{c}{$\begin{array}{c}\text { Cryptosporidium oocysts/ } \\
\text { HPF in stool samples }\end{array}$} \\
\cline { 2 - 4 } & Mean $\pm \mathrm{SD}$ & $\mathrm{K}$ test & $p$-value \\
\hline GI: Positive control (No.=18) & $18.88 \pm 4.36$ & $p 1<0.001$ \\
GII: E. purpurea $(\mathrm{No}=19)$ & $6.94 \pm 3.77$ & 56.13 & $p 2<0.001$ \\
GIII: NTZ (No. $=19)$ & $2.57 \pm 4.35$ & $p<0.001$ & $p 3<0.001$ \\
GIV: E. purpurea + NTZ (No. $=20)$ & $1.10 \pm 2.31$ & $p 4=0.02$ \\
& & $p 5<0.001$ \\
& & & $p 6=0.89$ \\
\hline
\end{tabular}

p1: GI vs. GII. p2: GI vs. GIII. p3: GI vs. GIV. p4: GII vs. GIII. p5: GII vs. GIV. p6: GIII vs. GIV.
Table (2): Comparison between mean Cryptosporidium endogenous developmental stages per one $\mathrm{C} / \mathrm{V}$ unit in the ilea of different studied groups on the last day of the experiment.

Groups

Cryptosporidium endogenous developmental stages per

\begin{tabular}{llll}
\hline & Mean \pm SD & U test & $p$-value \\
\hline GI: Positive control $($ No. $=18)$ & $31.72 \pm 4.14$ & 5.24 & $p 1<0.001$ \\
GII: E. purpurea $($ No. $=19)$ & $14.21 \pm 3.44$ & 5.27 & $p 2<0.001$ \\
GIII: NTZ $($ No. $=19)$ & $7.21 \pm 2.72$ & 5.34 & $p 3<0.001$ \\
GIV: E. purpurea + NTZ $($ No. $=20)$ & $3.50 \pm 2.24$ & 5.0 & $p 4=0.03$ \\
& & 5.41 & $p 5<0.001$ \\
& & 5.9 & $p 6<0.001$ \\
\hline
\end{tabular}

p1: GI vs. GII.

p3: GI vs. GIV.

p5: GII vs. GIV.

p2: GI vs. GIII. p6: GIII vs. GIV. 


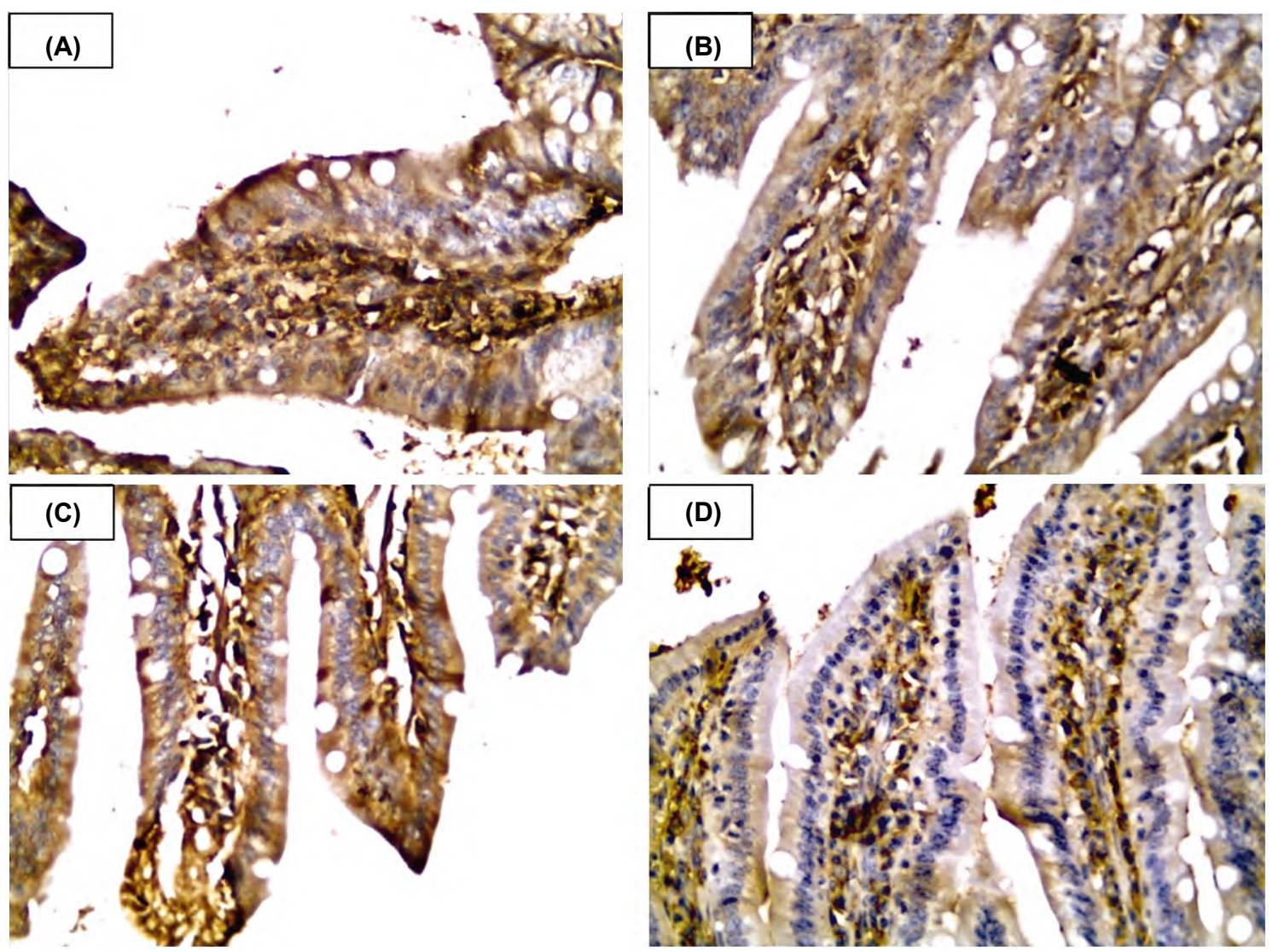

Fig. (4): (A): Ileum tissue of positive control group (GI) showing diffuse expression of Cox-2 in inflammatory cells within the core of intestinal villi with moderate expression in mucosal epithelial cells. (B): Ileum tissue of GII that received E.purpurea monotherapy showing negative expression of Cox-2 in epithelial cells and focal expression in inflammatory cells within the core of intestinal villi. (C): Ileum tissue of GIII that received NTZ monotherapy showing moderate expression of Cox-2 in epithelial cells and diffuse expression in inflammatory cells within the core of intestinal villi. (D): Ileum tissue of GIV that received combined therapy showing negative expression of Cox-2 in epithelium and inflammatory cells (Cox-2 immunostain, X400).

Table (3): Comparison between cure rates of cryptosporidiosis in the different studied groups.

\begin{tabular}{|c|c|c|c|c|c|c|}
\hline \multirow{2}{*}{ Groups } & \multicolumn{2}{|c|}{ Cured } & \multicolumn{2}{|c|}{ Non cured } & \multicolumn{2}{|c|}{ Fisher exact test } \\
\hline & No. & $\%$ & No. & $\%$ & & \\
\hline $\begin{array}{l}\text { - GI: Positive control }(\mathrm{No} .=18) \\
\text { - GII: E. purpurea }(\mathrm{No}=19) \\
\text { - GIII: NTZ }(\text { No. }=19) \\
\text { - GIV: E. purpurea }+ \text { NTZ }(\text { No. }=20)\end{array}$ & $\begin{array}{l}0 \\
8 \\
13 \\
18\end{array}$ & $\begin{array}{l}0 \\
42.1 \\
68.4 \\
90\end{array}$ & $\begin{array}{l}18 \\
11 \\
6 \\
2\end{array}$ & $\begin{array}{l}100 \\
57.9 \\
31.6 \\
10\end{array}$ & $\begin{array}{l}33.8 \\
p \text {-value } \\
<0.0001\end{array}$ & $\begin{array}{l}p 1=0.003 \\
p 2<0.001 \\
p 3<0.00001 \\
p 4=0.1 \\
p 5=0.0022 \\
p 6=0.127\end{array}$ \\
\hline
\end{tabular}

\begin{tabular}{lll}
\hline p1: GI vs. GII. & $p 3$ : GI vs. GIV. & $p 5$ : GII vs. GIV. \\
p2: GI vs. GIII. & $p 4:$ GII vs. GIII. & $p 6$ : GIII vs. GIV.
\end{tabular}

Table (4): Comparison between IL-17 expression in ileal sections of different studied groups.

\begin{tabular}{|c|c|c|c|c|c|c|c|c|c|c|c|c|c|}
\hline \multirow{3}{*}{ Groups } & \multicolumn{8}{|c|}{ IL-17 in the epithelial covering } & \multirow{3}{*}{$\begin{array}{l}\text { U- } \\
\text { test }\end{array}$} & \multirow{3}{*}{$\begin{array}{c}p- \\
\text { value }\end{array}$} & \multirow{3}{*}{$\begin{array}{l}\text { IL-17 in the } \\
\text { inflammatory } \\
\text { cells } \\
\text { Mean } \pm \text { SD }\end{array}$} & \multirow{3}{*}{$\begin{array}{l}\mathrm{U}- \\
\text { test }\end{array}$} & \multirow{3}{*}{$\begin{array}{c}p- \\
\text { value }\end{array}$} \\
\hline & \multicolumn{2}{|c|}{$\begin{array}{c}\text { Score 0: } \\
\text { Negative }\end{array}$} & \multicolumn{2}{|c|}{$\begin{array}{l}\text { Score I: } \\
\text { Mild }\end{array}$} & \multicolumn{2}{|c|}{$\begin{array}{l}\text { Score II: } \\
\text { Moderate }\end{array}$} & \multicolumn{2}{|c|}{$\begin{array}{l}\text { Score III: } \\
\text { Strong }\end{array}$} & & & & & \\
\hline & No. & $\%$ & No. & $\%$ & No. & $\%$ & No. & $\%$ & & & & & \\
\hline GI: Positive control $(\mathrm{No} .=18)$ & 0 & 0 & 0 & 0 & 0 & 0 & 18 & 100 & 37.0 & $p 1<0.001$ & $374.0 \pm 47.7$ & 5.24 & $p 1<0.001$ \\
\hline GII: E. purpurea $($ No. $=19)$ & 5 & 26.3 & 9 & 47.4 & 5 & 26.3 & 0 & & 5.48 & $p 2=0.02$ & $135.79 \pm 65.8$ & 5.24 & $p 2<0.001$ \\
\hline GIII: NTZ (No. $=19)$ & 5 & 26.3 & 0 & 0 & 0 & 0 & 14 & 73.7 & 38.0 & $p 3<0.001$ & $184.47 \pm 114.3$ & 5.30 & $p 3<0.001$ \\
\hline GIV: E. purpurea $+\mathrm{NTZ}\left(\mathrm{No}_{.}=20\right)$ & 5 & 25 & 0 & 0 & 15 & 75 & 0 & 0 & & $p 4<0.001$ & $32.25 \pm 16.41$ & 1.04 & $p 4=0.30$ \\
\hline & & & & & & & & & $\begin{array}{l}13.98 \\
28.99\end{array}$ & $\begin{array}{l}p 5=0.001 \\
p 6<0.001\end{array}$ & & $\begin{array}{l}5.38 \\
3.26\end{array}$ & $\begin{array}{l}p 5<0.001 \\
p 6<0.001\end{array}$ \\
\hline
\end{tabular}

p1: GI vs. GII.

p2: GI vs. GIII. $p 3$ : GI vs. GIV

$p 4$ : GII vs. GIII. p5: GII vs. GIV.
p6: GIII vs. GIV. 
Table (5): Comparison between Cox-2 expression in ileal sections of different studied groups.

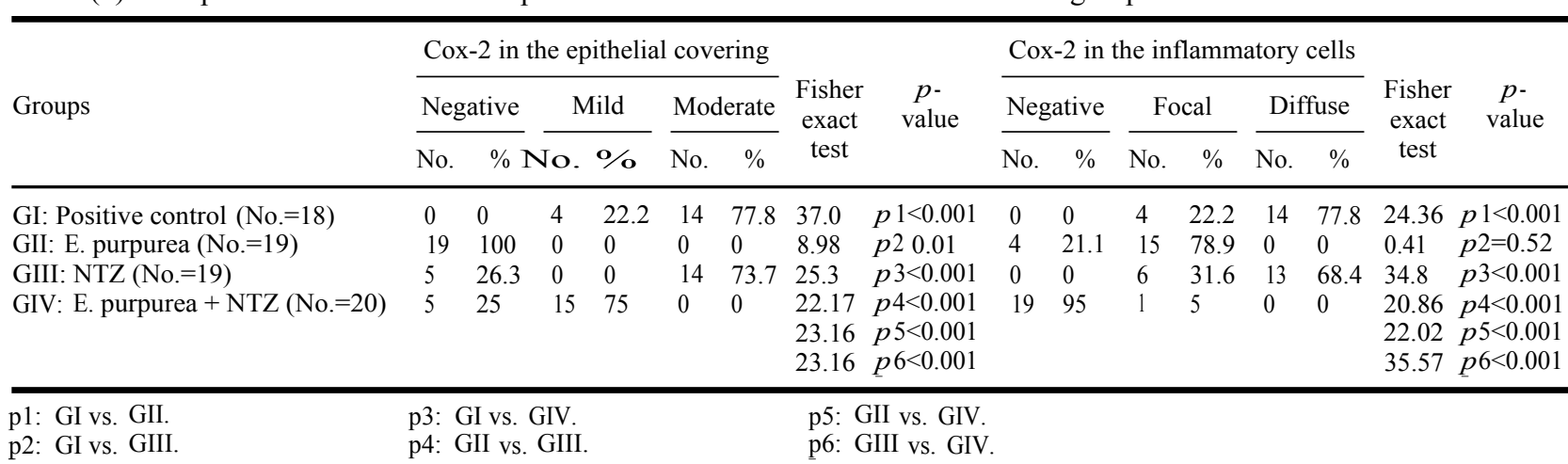

\section{Discussion}

Cryptosporidium is a protozoan parasite that usually infects the gastrointestinal tract of many vertebrate animals [48]. Nowadays, no effective treatment is available. The duration of disease is dependent upon the patient's immune status [18] Therefore, this work aimed to assess the in vivo activity of $E$. purpurea as an immunomodulatory agent in treatment of immunosuppressed mice experimentally infected with Cryptosporidium This study was carried out over a period of 30 days from the start of infection and all survived mice were euthanized on the 30 th dpi according to Lacroix et al., [49], who reported 3-4 weeks as the duration of Cryptosporidium oocyst shedding.

In this study, mortality rate of the positive control group (GI) was $10 \%$. This was in accordance with Sadek and El-Aswad, [13] who related this percentage either to Cryptosporidium infection itself or to immunosuppression state of mice that cause more severe course of infection. The mean oocyst shedding in this group was $18.88 \pm 4.36$ which was near those obtained by previous studies that insured high Cryptosporidium oocyst shedding in the immunocompromized mice $[\mathbf{3 8 , 5 0 - 5 2}]$. Sections of ilea of this group showed mucosal hyperplasia, decreased $\mathrm{C} / \mathrm{V}$ ratio, blunting of villi, dense inflammatory infiltrate in the lamina propria, goblet cells depletion, moderate reactive atypia and low grade dysplasia in the covering epithelium. The endogenous developmental stages of Cryptosporidium were easily seen either on the tip of the villi or within the epithelium with mean $31.72 \pm 4.14$. These histopathological changes were in accordance with previous studies by Ollivett et al., [53], Sadek and El-Aswad, [13] and Mahmood et al., [54] who recorded nearly the same results. Moreover, IL-17 immunohistochemical staining of GI showed strong grade of positivity in $100 \%$ of the covering epithe- lium with positive cytoplasmic staining in $374.0 \pm$ 47.7 of infiltrating chronic inflammatory cells in lamina propria. These results were in accordance with Zhao et al., [12], Zhao et al., [55] and Drinkall et al., [56] . Regarding Cox-2 stain, most sections $(77.8 \%)$ showed moderate expression of Cox-2 in epithelial cells as well as diffuse expression in inflammatory cells in lamina propria. These results were supported by Assad and Sadek, [57] \& Sadek and El-Aswad [13] who considered a strong relation between Cox-2 expression and C. parvum infection. They reported that Cox-2 mediates Cryptosporidium induced inflammatory responses.

Anti-Cryptosporidium activity of E. purpurea as a single therapy (GII) was assessed in this study. To the best of our knowledge, this is the first study that determines possible effectiveness of E. purpurea in treatment of cryptosporidiosis. Mortality rate in GII was 5\%. This was less than mortality rates recorded by other treatments previously used in treatment of experimental cryptosporidiosis as miltefosine used by Mahmood et al., [54] which caused $12.5 \%$ mortality rate in treated mice. This also, was much less than mortality rate recorded by Soufy et al., [58] which was $30 \%$ in C. parvum infected rats treated with propolis. Echinacea also significantly reduced the mean oocyst shedding in stool and the mean number of the endogenous developmental stages when compared to the positive control group (GI) but to less extent than NTZ treated group (GIII). Nitazoxanide significantly reduced both parameters when compared to GI or GII. This was in accordance with Sadek and El Aswad, [13] who reported 7.13 and 6.18 as mean oocyst shedding and mean endogenous developmental stages, respectively in NTZ treated mice which were significantly less than those of the positive control group. E. purpurea extract caused cure rate of $42.1 \%$ that showed insignificant difference when compared to NTZ (68.4\%), it obvi- 
ously improved the histopathological abnormalities in ileum stained sections. These results may be related to the immunomodulatory and regenerative properties of Echinacea that were previously reported by Zhai et al., [23], who reported that Echinacea polysaccharide components can reduce the inflammatory responses to different infections and can accelerate tissue regeneration. These results may be also explained by a direct anti-parasitic effect of Echinacea. Anti-parasitic activities of Echinacea were previously reported. Canlas et al., [59], Junior et al., [39], and Kumosani and Barbour, [60] reported efficacy of Echinacea in treatment of Leishmania, Trypanosoma, apicomplexan Eimeria and their associated lesions. The anti-parasitic mechanisms of $E$. purpurea on these parasites are still unknown. It may differ between species, however microscopic observations of Echinacea treated parasites showed slowing or stopping of their motility [24].

Regarding results of immunohistochemical staining of GII, Echinacea significantly reduced IL-17 and Cox- 2 in both epithelial covering and inflammatory cells in lamina propria when compared to the positive control group. These results were similar to those obtained by Saki et al., [31] who reported that the use of E. purpurea can interfere with IL-17 gene expression and can down regulate Cox-2 enzyme. Moreover, Echinacea reduction of Cox-2 was supported by previous studies [61,62]. This Cox-2 reduction can be a mechanism of action against Cryptosporidium infection and can cause improvement of Cryptosporidium associated pathological lesions. This was supported by Mulshine et al., [20] who reported that drugs that blocks Cox-2 represent an effective strategy for decreasing different inflammatory conditions. Asaad and Sadek, [57] \& Sadek and ElAswad, [13] reported that Cox-2 inhibition has beneficial a role in treatment of cryptosporidiosis.

As regards GIV that received combined therapy, it showed the best results regarding mortality rates $(0 \%)$, oocyst shedding $(1.10 \pm 2.31)$, endogenous developmental stages $(3.50 \pm 2.24)$ and cure rates (90\%). It also showed the most improvement of all histopathological lesions as only the house keeping inflammatory cells were present with preserved polarity of epithelium which was devoid of any atypia. This was further supported by the statistically significant reduction of IL-17 and Cox2 expression in inflammatory cells, where the mean expression of IL-17 was (32.25 \pm 16.41$)$ and Cox2 expression was negative in $95 \%$ of cells with a significant difference when compared to GI, GII and GIII.
These encouraging results can be attributed to the merged anti-parasitic effect of NTZ and immmunomodulatory effect of $E$. purpurea which was reported as a wide spectrum immunomodulatory therapy that can stimulate both natural and acquired immune responses [63]. Previous studies stated that combination therapy in general usually gives better results in controlling C. parvum infections than monotherapy $[\mathbf{1 3 , 4 8 ]}$. Echinacea combinations previously increased the survival of $T$. gondii infected mice [64].

Incomplete disappearance of Cryptosporidium oocysts and endogenous developmental stages from the stool and ileum respectively in GIV, can be explained by suppression of the immune system of mice, making clearance of Cryptosporidium very difficult as a competent host immune system is needed for rejection of Cryptosporidium parasites as stated by Gargala, [17].

\section{Conclusion:}

The results obtained by this study suggest that E. purpurea has important therapeutic activities in immunosuppressed experimentally infected mice with Cryptosporidium . Combining E. purpurea with NTZ represents significant advances in treatment of experimental cryptosporidiosis in dexamethasone-immunosuppressed mice.

\section{Conflicts of interest:}

No conflicts of interest declared.

\section{Authors' contributions:}

All authors had equal roles in study design, work, statistical analysis and manuscript writing. All authors have approved the final article work.

\section{References}

1- KHAN A., SHAIK J.S. and GRIGG M.E.: Genomics and molecular epidemiology of Cryptosporidium species. Acta. Tropica., 184: 1-14, 2018.

2- NASSER A.M.: Removal of Cryptosporidium by wastewater treatment processes: A review. J. Water and Health. 14: 1-13, https://doi.org/10.10.2166/wh.2015.131, 2016.

3- ABEYWARDENA H., JEX A.R. and GASSER R.B.: A perspective on Cryptosporidium and Giardia, with an emphasis on bovines and recent epidemiological findings. Advances in Parasitology, 88: 243-301, 2015.

4- BARAKAT F.M., McDONALD V., FOSTER G.R., TOVEY M.G. and KORBEL D.S.: Cryptosporidium parvum infection rapidly induces a protective innate immune response involving type I interferon. J. Infect. Dis., 200 (10): 1548-55, http://dx.doi.org/10.10.1086/644601, 2009.

5- CHECKLEY W., WHITE A.C., JAGANATH D., ARROWOOD M.J. and CHALMERS R.M.: A review of the global burden, novel diagnostics, therapeutics, and vaccine targets for Cryptosporidium . Lancet. Infect. Dis., 15: 85-94, 
http://dx.doi.org/10.10.1016/S1473-3099(14)70772-8. 2015.

6- CERTAD G.A., ARENAS-PINTO L., POCATERRA G., FERRARA J. and CASTRO A.: Cryptosporidiosis in HIVinfected Venezuelan adults is strongly associated with acute or chronic diarrhea. Am. J. Trop. Med. Hyg., 73: 54-7, 2005.

7- PALMIERI F., CICALINI S., FROIO N., RIZZI E.B., GOLETTI D., FESTA A., MACRÍ G. and PETROSILLO N.: Pulmonary cryptosporidiosis in an AIDS patient: Successful treatment with paromomycin plus azithromycin. Int. J. STD. AIDS. 16: 515-517, https://doi.org/10.10.1258/ 0956462054308332, 2005.

8- GUERRANT D.I., MOORE S.R., LIMA A.A., PATRICK P.D., SCHORLING J.B. and GUERRANT R.L.: Association of early childhood diarrhea and cryptosporidiosis with impaired physical fitness and cognitive function four-seven years later in a poor urban community in northeast Brazil. Am. J. Trop. Med. Hyg., 61: 707-13, 1999.

9- XIAO L., FAYER R., RYAN U. and UPTON S.J.: Cryptosporidium taxonomy: Recent advances and implications for public health. Clin. Microbiol. Rev., 17: 72-7, 2004.

10-ASADPOUR M., NAMAZI F., RAZAVI S.M. and NAZIFI S.: Comparative efficacy of curcumin and paromomycin against Cryptosporidium parvum infection in a BALB/c mode. Vet. Parasitol., 250: 7-14, http://dx.doi.org/ 10.10.1016/j.vetpar.2017.12.008, 2018.

11- MEAD J.R.: Prospects for immunotherapy and vaccines against Cryptosporidium. Hum. Vaccin. Immunother., 10 (6): 1505-13, https://doi.org/10.10.4161/hv.28485, 2014.

12-ZHAO G.H., CHENG W.Y., WANG W., JIA Y.Q., FANG Y.Q., DU S.Z. and YU S.K.: The expression dynamics of IL-17 and Th17 response relative cytokines in the trachea and spleen of chickens after infection with Cryptosporidium baileyi. Parasit. Vectors. 7: 212, https://doi.org/10 10.1186/1756-3305-7-212, 2014.

13- SADEK G.S. and EL-ASWAD B.E.: Role of COX-2 in Pathogenesis of intestinal cryptosporidiosis and effect of some drugs on treatment of infection. Res. J. Parasitol., 9: 21-40, https://doi.org/10.10.3923/jp.2014.21.40, 2014.

14- VALDEZ P.A., VITHAYATHIL P.J., JANELSINS B.M., SHAFFER A.L., WILLIAMSON P.R. and DATTA S.K.: Prostaglandin E2 suppresses antifungal immunity by inhibiting interferon regulatory factor 4 function and interleukin-17 expression in T cells. Immunity., 36: 66879, https://doi.org/10.10.1016/j.immuni.2012.02.013, 2012.

15- ABUBAKAR I., ALIYU S.H., ARUMUGAM C., HUNTER P.R. and USMAN N.K.: Prevention and treatment of cryptosporidiosis in immunocompromised patients. Cochrane Database Syst. Rev., 24: 1, http://dx.doi.org/ 10.10.1002/14651858.CD004932.pub2, 2007.

16- AMADI B., MWIYA M., SIANONGO S., PAYNE L., WATUKA A. KATUBULUSHI M. and KELLY P.: High dose prolonged treatment with nitazoxanide is not effective for cryptosporidiosis in HIV positive Zambian children: a randomised controlled trial. B.M.C. Infect. Dis., 9: 195, http://dx.doi.org/10.10.1186/1471-2334-9-195, 2009.
17- GARGALA G.: Drug treatment and novel drug target against Cryptosporidium . Parasite, 15: 275-81, http:// . dx.doi.org/10.10.1051/parasite/2008153275, 2008.

18- XIAO L.: Molecular epidemiology of cryptosporidiosis: An update. Exp. Parasitol., 124 (1): 80-9, https://doi.org/ 10.10. 1016/j.exppara.2009.03.018, 2010.

19- SCHAEFER D.A., BETZER D.P., SMITH K.D., MILLMAN Z.G., MICHALSKI H.C., MENCHACA S.E., ZAMBRISKI J.A., OJO KKHULVERSON M., ARNOLD S.L., RIVAS K.L., VIDADALA R.S., HUANG W., BARRETT L.K., MALY D.J., FAN E., VAN VOORHIS W.C. and RIGGS M.W.: Novel bumped kinase inhibitors are safe and effective therapeutics in the calf clinical model for cryptosporidiosis. J. Infect. Dis., 214: 1856-64, https:// . doi.org/10.10.1093/infdis/jiw488, 2016.

20- MULSHINE J.L., ATKINSON J.C., GREER R.O., PAPADIMITRAKOPOULOU V.A., WAES C., RUDY S., MARTIN J.W., STEINBERG S.M., LIEWEHR D.J., AVIS I., LINNOILA R.I., HEWITT S., LIPPMAN S.M., FRYE R. and CAVANAUGH P.F.: Randomized, double-blind, placebo-controlled phase IIB trial of the cyclooxygenase inhibitor ketorolac as an oral rinse in oropharyngeal leukoplakia. Clin. Cancer. Res., 10 (5): 1565-73, https:// . doi.org/10.10.1158/1078-0432.CCR-1020-3, 2004.

21- SHISHODIA S., KOUL D. and AGGARWAL B.B.: Cyclooxygenase (COX)-2 inhibitor celecoxib abrogates TNF-induced NF- $\mathrm{KB}$ activation through inhibition of activation of IKBa kinase and akt in human non-small cell lung carcinoma: Correlation with suppression of COX-2 synthesis. J. Immunol., 173 (3): 2011-22, https:// . doi.org/10.jimmunol.173.3.2011, 2004.

22- BORCHERS A.T., KEEN C.L., STERN J.S. and GERSHWIN M.E.: Inflammation and native American medicine: The role of botanicals. Am. J. Clin. Nutr., 72: 339-47, http://dx.doi.org/10.10.1093/ajen/72.2.339, 2000.

23- ZHAI Z., HANEY D.M., WU L., SOLCO A.K., MURPHY P.A., WURTELE E.S., KOHUT M.I. and CUNNICK J.E.: Alcohol extract of Echinacea pallidareverses stressdelayed wound healing in mice. Phytomedicine, 16: 66978, https://doi.org/10.10.1016/j.phymed.2009.02.010, 2009.

24- HUDSON J.B.: Applications of the phytomedicine Echinacea purpurea (Purple Coneflower) in infectious diseases. J. Biomed. Biotech., 2012: 16, http://dx.doi.org/10.1155/ 2012/769896, 2012.

25- MANAYI A., VAZIRIAN M. and SAEIDNIA S.: Echinacea purpurea: Pharmacology, phytochemistry and analysis methods. Pharmacogn. Rev., 9 (17): 63-72, https://doi.org/ 10.10.4103/0973-7847.156353, 2015.

26- AARLAND R.C., BANUELOS-Hernandez A.E., FRAGOSO-SERRANO M., SIERRA-PALACIOS E.D., De LEON-SANCHEZ D., PEREZ-FLORES L.J. and MENDOZA-ESPINOZA J.A.: Studies on phytochemical, antioxidant, anti-inflammatory, hypoglycaemic and antiproliferative activities of Echinacea purpurea and Echinacea angustifolia extracts. Pharm. Biol., 55 (1): 649-56, http:// . dx.doi.org/10.1080/13880209.2016.1265989, 2017.

27- CHIOU S.Y., SUNG J.M., HUANG P.W. and LIN S.D.: Antioxidant, antidiabetic, and antihypertensive properties of Echinacea purpureaflower Extract and caffeic acid derivatives using in vitro Models. J. Med. Food., 20 (2): 171-9, http://dx.doi.org/10.1089/jmf.2016.3790, 2017. 
28- AYRLE H., MEVISSEN M., KASKE M., NATHUES H., GRUTEZNER N. MELZIG M. and WALKENHORST M.: Medicinal plants-prophylactic and therapeutic options for gastrointestinal and respiratory diseases in calves and piglets? A systematic review. B.M.C. Veterinary Research, 12: 89, http://dx.doi.org/10.10.1186/s12917-016-0714-8, 2016.

29- WANG C., HOU Y., LV Y., CHEN S., ZHOU X., ZHU R., WANG J., JIA W. and WANG X.: Echinacea purpurea extract affects the immune system, global metabolome, and gut microbiome in wistar rats. J. Agricultural Science. 9: (4), https://doi.org/10.5539/jas.v9n4p1, 2017.

30- BENSON J.M., POKORNY A.J., RHULE A., WENNER C.A., KANDHI V., CECH N.B. and SHEPHERD D.M.: Echinacea purpurea extracts modulate murine dendritic cell fate and function. Food. Chem. Toxicol., 48 (5): 11707, 2010.

31- SAKI A.A., SIYAR S.A.H. and ASHOORI A.: Modulation of lipopolysaccharide induced interleukin-17F and cyclooxygenase- 2 gene expression by Echinacea purpurea in broiler chickens. International Journal of Animal and Veterinary Sciences, 11 (11): 778-81, 2017.

32- HENRIKSEN S.A. and POHLENZ J.F.: Staining of cryptosporidia by a modified Ziehl-Neelsen technique. Acta. Vet. Scand., 22: 594-6, 1981.

33- ARROWOOD M.J. and STERLING C.R.: Isolation of Cryptosporidium oocysts and sporozoites using discontinuous sucrose and isopycnic percoll gradients. J. Parasitol., 73: 314-9, 1987.

34- WEE S.H., LEE C.G., KIM B.S., JOO H.D. and KANG S.W.: Isolation of Cryptosporidium parvum oocysts from fecal samples: The co.mbination of ether extraction and discontinuous sucrose gradients. Korean J. Parasitol., 32 (1): 7-12, https://doi.org/10.3347/kjp.1994.32.1.7, 1994.

35- SURESH P. and REHG J.E.: Comparative evaluation of several techniques for purification of Cryptosporidium parvum oocysts from rat feces. J. Clin. Microbiol., 34: 38-40, 1996.

36- REHG J.E., HANCOCK M.L. and WOODMANSEE D.B.: Characterization of a dexamethasone treated rat model of cryptosporidial infection. J. Infect. Dis., 158: 1406-7, https://doi.org/10.1093/infdis/158.6.1406, 1988.

37- PAGET G.E. and BARNES J.M.: Evaluation of drug activities. In: Laurence DR, Backarach AL, editors. Pharmacometrics. London and New York: Academic Press; 1964.

38- ABDOU A.G., HARBA N.M., AFIFI A.F. and ELNAIDANY N.F.: Assessment of Cryptosporidium parvum infection in immunocompetent and immunocompromised mice and its role in triggering intestinal dysplasia. Int. J. Infect. Dis., 17 (8): 593-600, http://dx.doi.org/10.10.1016/ j.ijid.2012.11.023, 2013.

39- JUNIOR A.G., COSMO M.L.A., De PAULA REIS M., SANTOS P.S.D., GONÇALVES D.D., GASPAROTTO F.M., NAVARRO A.T. and LOURENÇO E.L.B.: Effects of extracts from Echinacea purpurea $(\mathrm{L})$ Moench on mice infected with different strains of Toxoplasma gondii. Parasitol. Res., 115 (10): 3999-4005, http://dx.doi.org/ 10.10.1007/s00436-016-5167-2, 2016.

40- MEAD J.R., ARROWOOD M.J., SIDWELL R.W. and HEALEY M.C.: Chronic Cryptosporidium parvum infec- tions in congenitally immunodeficient SCID and nude mice. J. Infect. Dis., 168: 1297-304, 1991.

41- HEALEY M.C., YANG S., RASMUSSEN K.R., JACKSON M.K. and Du C.: Therapeutic efficacy of paromomycin in immunosuppressed adult mice infected with Cryptosporidium parvum. J. Parasitol., 81: 114-6, 1995.

42- HAMILTON S.R., BOSMAN F.T., BOFFETTA P., ILYAS M., MORREAU H., et al.: Carcinoma of the colon and rectum. In: Bosman FT, Carniero F, Hruban RH, Theise ND, editors. WHO Classification of Tumours of the Digestive System (4 th ed). Lyon: IARC Press, 2010.

43- HULL M.A., BOOTH J.K., TISBURY A., SCOTT N., BONIFER C., MARKHAM A.F. and COLETTA P.L.: Cyclooxygenase 2 is up-regulated and localized to macrophages in the intestine of Min mice. British. J. Cancer, 79 (9/10): 1399-405, http://dx.doi.org/10.10.1038/ sj.bjc.6690224, 1999.

44- Du W.J., ZHEN J.H., ZENG Z.Q., ZHENG Z.M. and Xu Y.: Expression of Interleukin-17 associated with disease progression and liver fibrosis with hepatitis $B$ virus infection: IL-17 in HBV infection. Diagn. Pathol., 8: 40, http://dx.doi.org/10.10.1186/1746-1596-8-40, 2013.

45- FUJINO S., ANDOH A., BAMBA S., OGAWA A., HATA K., ARAKI Y., BAMBA T. and FUJIYAMA Y.: Increased expression of IL-17 in inflammatory bowel disease. Gut., 52 (1): 65-70, 2003.

46- SHAMMA A., YAMAMOTO H., DOKI Y., JIRO OKAMI., KONDO M., FUJIWARA Y., YANO M., INOUE M., MATSUURA N., SHIOZAKI H. and MONDEN M.: Upregulation of cyclooxygenase-2 in squamous carcinogenesis of the esophagus. Clin. Cancer Res., 6: 1229-38, 2000.

47- NOFECH-MOZES S., KUPETS R., RASTY G., ISMIIL N., COVENS A. and KHALIFA M.A.: Cyclooxygenase2 (Cox-2) immunostaining does not correlate with the degree of vulvar neoplasia. J. Obstet. Gynaecol. Can., 28: 290-4, https://doi.org/10.10.1016/S1701-2163(16) 32134-X, 2006.

48- MOHAMED E.A., ZALAT R.S., MAGDI M., GUIRGUIS N. and MAHMOUD S.: Effect of combined therapy with albendazole and sutrim in experimental Cryptosporidiosis. Global Veterinaria, 15 (2): 144-9, https://doi.org/ 10. 10.5829/idosi.gv.2015. 15.02.9640, 2015.

49- LACROIX S., MANCASSOLA R., NACIRI M. and LAURENT F.: Cryptosporidium parvum -specific mucosal immune response in C57BL/6 neonatal and gamma interferon-deficient mice: Role of tumor necrosis factor alpha in protection. Infect. Immun., 69: 1635-42, https://doi.org/ 10.10.1128/IAI.69.3.163 5-1642.2001, 2001.

50- BAISHANBO A., GARGALA G., DELAUNAY A., FRANCOIS A., BALLET J.J. and FAVENNEC L.: Infectivity of Cryptosporidium hominis and Cryptosporidium parvumgenotype 2 isolates in immunosuppressed Mongolian gerbils. Infect. Immun., 73: 5252-5, http:// dx.doi.org/10.10.1128/IAI.73.8.5252-5255.2005, 2005.

51- CERTAD G., NGOUANESAYANH T., GUYOT K., GANTOIS N., CHASSAT T., MOURAY A., FLEURISSE L ., PINON A., CAILLIEZ J., DEI-CAS E. and CREUS Y.: Cryptosporidium parvum, a potential cause of colic adenocarcinoma. Infect. Agent. Cancer, 2: 22, http://. dx.doi.org/10.10.1186/1750-9378-2-22, 2007. 
52- ROSSIGNOL J.F.: Cryptosporidium and Giardia: Treatment options and prospects for new drugs. Exp. Parasitol., 124: 45-53, https://doi.org/10.10.1016/j.exppara.2 009.07. $005,2010$.

53- OLLIVETT T.L., NYDAM D.V., BOWMAN D.D., ZAMBRISKI J.A., BELLOSA M.L., LINDEN T.C. and DIVERS T.J.: Effect of nitazoxanide on cryptosporidiosis in experimentally infected neonatal dairy calves. J. Dairy. Sci., 92 (4): 1643-8, https://doi.org/10.10.3168/jds.20081474, 2009.

54- MAHMOOD M.N., RAMADAN F.N., HASSAN M.S., SABRY H.Y. and MAGDY M.M.: Introducing miltefosine as an anti-cryptosporidial agent in immunocompromised mice. J. Plant. Pathol. Microbiol., 7: 354, https://doi.org/ 10.10.4172/2157-7471.1000354, 2016.

55- ZHAO G.H., FANG Y.Q., RYAN U., GUO Y., WU F., DU S.Z., CHEN D.K. and LIN Q.: Dynamics of Th17 associating cytokines in Cryptosporidium parvum -infected mice. Parasitol. Res., 115: 879-87, https://doi.org/ 10.10.1007/s00436-015-4831-2, 2016.

56- DRINKALL E., WASSA M.J., COFFEYA T.J. and FLYNNA R.J.: A rapid IL-17 response to Cryptosporidium parvum in the bovine intestine. Vet. Immunol. Immunopathol., 191: 1-4, http://dx.doi.org/10.10.1016/j.vetimm 2017.07.009, 2017.

57- ASAAD N.Y. and SADEK G.S.: Pulmonary cryptosporidiosis: Role of COX2 and NF-Kb. J. Patho. Microbial. Immunol., 114 (10): 682-9, http://dx.doi.org/10.10.3923/ jp.2014.21.40, 2006.

58- SOUFY H., NADIA M., NASR S.M., ABD EL-AZIZ T.H., KHALIL F.A.M., AHMED Y.F. and ABOU ZEINA H.A.A.: Effect of Egyptian propolis on cryptosporidiosis in immunosuppressed rats with special emphasis on oocysts shedding, leukogram, protein profile and ileum histopathology. Asian Pacific J. Trop. Med., 10 (3): 25362, https://doi.org/10.1016/j.apjtm.2017.03.004, 2017.

59- CANLAS J., HUDSON J.B., SHARMA M. and NANDAN D.: Echinacea and Trypanosomatid parasite interactions: growth inhibitory and anti-inflammatory effects of Echinacea. Pharm. Biol., 48 (9): 1047-52, http://dx.doi.org/ 10.10.3109/13880200903483468, 2010.

60- KUMOSANI T. and BARBOUR E.K.: Evaluation of performance and immunomodulation in Eimeria spp and Clostridium perfringens -challenged broilers administered intermittently an Echinacea-based preparation. Intern. J. Appl. Res. Vet. Med., 14: 1, https://doi.org/10.10.4172/ 2155-9600.C1.030, 2016.

61- CLIFFOED L.J., NAIR M.G., RANA J. and DEWITT D.L.: Bioactivity of alkamides isolated from Echinacea purpurea (L.) Moench. Phytomedicine , 9 (1): 249-53, http://dx.doi.org/10.10.1078/0944-7113-00105, 2002.

62- SHARMA M., ANDERSON S.A., SCHOOP R. and HUDSON J.B.: Induction of multiple pro-inflammatory cytokines by respiratory viruses and reversal by standardized Echinacea, a potent antiviral herbal extract. Antiviral Research, 83 (2): 165- 70, https://doi.org/10.10.1016/ j.antiviral.2009.04.009, 2009.

63- ZHAI Z., LIU Y., WU L., SENCHINA D.S., WURTELE E.S., MURPHY P.A., KOHUT M.L. and CUNNICK J.E.: Enhancement of innate and adaptive immune functions by multiple Echinacea species. J. Med. Food, 10 (3): 42334, https://doi.org/10.10.1089/jmf.2006.257, 2007.

64- KÖKSAL Z.S., YANIK K., BILGIN K., YILMAZ E.M. and HOKELEK M.: In vivo efficacy of drugs against Toxoplasma gondii combined with immunomodulators. J. Infect. Dis., 69: 113-7, https://doi.org/10.10.7883/ yoken.JJID.2015.023, 2016. 


\section{تأثيرات الإيشينيسيا بيربوريا على الكريبتوسبوريلإيوسيس المعنداهيس

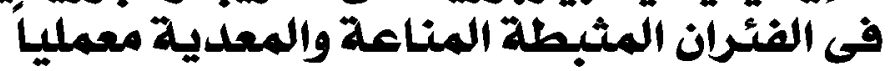

إن الكريبتوبسويديوم هو واحد من طفيليات الكوكسيديا المنتشرة فى جميع آنحاء العالم ويعتبر العبب الثانى للإسهال والموت عند الآطفال بعد فيروس الروتا . إن خيارات العلاج الحالية للكريبتوبسوريديويسيس محدودة للغاية و لذلك فهناك حاجة ملحة لتطوير علاجها .

الهدف من الدراسة: تقييم تآثيرات الإيشينيسيا بيربويا فى علاج الكرييتوبسويديوبيس فى الفئران المعدية معمليا ذوى المناعة المثبطة.

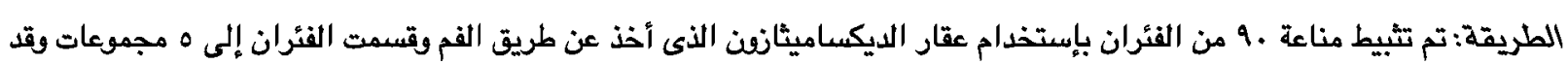

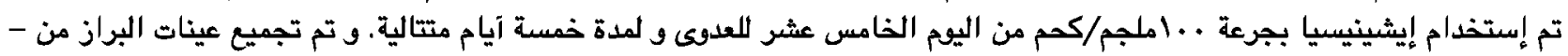

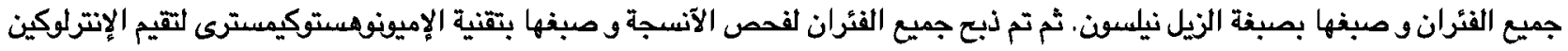

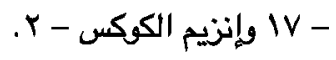

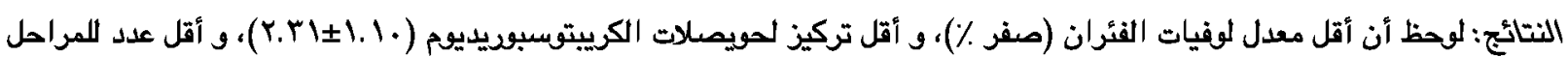

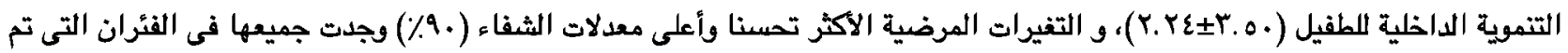

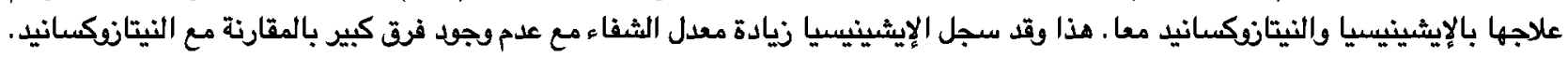

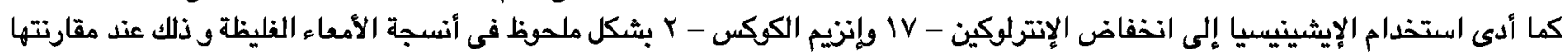
مع مجموعة الإيجابية الضابطة. الخلاصدة: لقد خلصنا من هذه الدراسة إلى أن إستخدام الإيشينيسيا بيريويا و عقار النيتانفكسانيد معاً يمثل تقدما كبيرا فى علاج

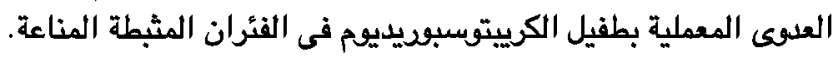

